\title{
BLACK POLITICAL ATTITUDES AND POLITICAL RAP MUSIC ${ }^{1}$
}

\author{
Lakeyta M. Bonnette \\ Georgia State University
}

In 2005, Chicagoan rap artist Kanye West, one of Hip-Hop's most defiant and politically incorrect rappers, decided to deviate from the teleprompter before him and instead voice his opinion on live television during a fundraiser to raise money for the victims of Hurricane Katrina, and the rebuilding of New Orleans. When it was his turn to speak, West publicly stated "George Bush doesn't like Black people." The shocking comment caught the co-host of the telethon, Michael Myers, and the producers by surprise. After days of watching Black people in New Orleans wade through filthy water, beg to be saved from their flooded homes and be referred to as "refugees" West was simply stating the opinion of many Blacks. From West's and many other Black Americans' perspective the government could not possibly care about the displacement and agony that victims of hurricane Katrina in New Orleans experienced based on its response. West identified former President Bush as the main culprit because he, as the nation's chief executive, represented the head of the American government. While the lack of efficient government response to its citizens shocked the world, many African Americans viewed the Federal Emergency Management Agency's inept response as simply another link in the chain of political exclusion, lack of support and disregard experienced by a marginalized community. Even before West made his statement, the slow response had been framed as a racial and class issue. In homes, barbershops, beauty salons, around water coolers and other gathering spots the sentiment was that if the disaster had occurred in a city where the majority residents affected had been White and middle class, the response would have been completely different. ${ }^{2}$

West was following a tradition of musicians who used their popularity and celebrity status to speak for those whose voices and concerns are often not considered (Iton, 2008). From Scott Joplin to Marvin Gaye to

* Acknowledgements: I would like to thank those who have read various iterations of this work including, but not limited to Niambi Carter, Randy Burnside and Byron D'Andra Orey. For a more detailed discussion of the points made in this article please see Pulse of the People: Political Rap Music and Black Political Attitudes by Lakeyta M. Bonnette from the University of Pennsylvania Press. Thanks also go to all of the scholars who have paved a way in this area of examining culture and politics.

2 http://www.cbsnews.com/stories/2005/09/03/katrina/main814623.shtml 
now, Kanye West, there has been a history of African American celebrities utilizing their notoriety to demand a seat at the political table to advocate against injustice and provide a voice for the voiceless. Billie Holiday's "Strange Fruit" about the lynching of Blacks or Same Cooke's "A Change is Gonna Come" are examples of discussing the government's lack of response to African Americans in a time of need. Thus, Blacks have used both overt and covert measures to resist injustice and demand equality.

It is posited that "Black music may be viewed as a symbolization of the Black experience" (Walker 1975, 2). One can gain an understanding of the various struggles and issues encountered by Blacks throughout their history in America by studying various forms of Black music during different eras. Culture, specifically Black music, historically, has been a resistance mechanism that Blacks utilized to assert their visibility in arenas in which majority players deemed them invisible. Blacks have used culture to disseminate information, increase solidarity, fight against injustice and maintain political and social movements. Culture has allowed those who typically do not have a voice to assert their demands in political and social spheres from which they were systematically ostracized. Music in the Black community has always represented a counterpublic for the ideas and attitudes of this community and has been significant to resistance struggles for African Americans (Spence 2011; Ogbar 2007; Levine 2006; Norfleet 2006; Harris-Lacewell 2004; Pough 2004). However, one may question is there a particular Black ideology presented within political rap songs? I argue that yes, Black Nationalism is a dominant ideology presented within rap songs and this can be observed by analyzing political rap lyrics. This article examines the relationship between music and attitudes by observing the Black Nationalist attitudes presented in political rap songs.

\section{RaP Music}

The oral tradition has been used regularly in the Black community as a means to articulate feelings and attitudes of members of the Black community. Out of this oral tradition arose one of the most influential music genres, rap music. It is widely concluded that rap music began with the Last Poets and the poetry of Gil Scott-Heron in the early 1970's (Allen 1996; Ards 2004; Henderson 1996). The Last Poets and Gil Scott-Heron incorporated unique styles in which they recited poetry over musical beats. While this style can be described as one of the foundations of modern rap many will trace the style of rap back further to the oral tradition of African griots and Black leaders (Kitwana 2002). Additionally, in rap there is a direct connection with the oral rhetoric of prominent Black leaders, demonstrating its commitment to the oral tradition. 
Rap is defined as "a form of rhymed storytelling accompanied by highly rhythmic, electronically based music" and "a Black cultural expression that prioritizes Black voices from the margins of urban America" (Rose 1994, 2). Similarly, Lusane (2004) defines rap as ". . the voice of the alienated, frustrated and rebellious Black youth who recognize their vulnerability and marginality in post-industrial America" (351). It is asserted that "members of the Hip-Hop movement started their disruption by making music and creating spaces for themselves when everything around them suggested exclusion" (Pough 2004, 287). Therefore, rap music was one avenue for marginalized African Americans to voice their discontent and present issues relevant to their segment of the population. Rap was largely a type of party music where the main emphasis was on the creativity of the disc-jockey (Rose, 1994). However, rap began to change and "no longer was it simply 'party' music but had taken on the character of a . . p political movement that embraced themes of Black Nationalism" (Southern 1997, 600).

From its beginnings in New York, rap has been a vehicle for the young and disenfranchised. Early on it provided dispatches from America's crumbling inner cities ravaged by crack cocaine, violence and apathy from elected officials. It has evolved into a multi-billion dollar industry, whose stars accumulate wealth its pioneers could only have imagined. Rap is used to sell everything from Hillshire Farms meat to sneakers and cars (Ogbar 2007). Yet in 2013, the political and economic circumstances which gave rise to this music genre persist.

Political rap, a subgenre of the larger rap genre, follows the model of uniting African Americans through music by discussing issues relevant to the Black community and providing information about injustices the community members face. Rap in general is influential. Michael Dawson (1999) states, “. . . rap has become an integral part of a grapevine that is constantly critiquing the state of American race relations" (322). Similarly, the music of the Hip-Hop generation is critical for knowledge, awareness, mobilization and action. Rap has a future as a political agent. In fact, Gwendolyn Pough (2004) contends that “. . .rap's ability to move the crowd has the possibility to do more than make them dance; it could very well be used to spark political activism" (194). However, it has been debated how much of an impact music has on the political attitudes of a listener (Henry 1990).

For example, Lester Spence (2011) argues that rap does impact Black political attitudes but not always in the direction proponents of Hip-Hop suggest. Spence argues that there is a relationship between rap consumption and support of Black Nationalist tenets as well as a heightened criticism of the American legal system. He also concludes that those who consume rap are more xenophobic (Spence 2011). Similarly, 
Cathy Cohen (2010) finds in her research that exposure to rap music also impacts the political attitudes of youth. Specifically, those who are exposed to rap assert more alienation from the political system but many youth do not think that rap music should be more political (Cohen 2010). These analyses are excellent and represent initial examinations of the influence of rap on political attitudes; however, this research does lack a crucial element that will allow political scientists, politicians and music artists to make a more concrete decision about how much rap music has an influence on political attitudes and that is the differentiation of subgenres of rap music. One cannot discuss rap as if it is a homogenous genre espousing one set of views and attitudes. Like the Black community, there are variations within Hip-Hop that demand separate analysis of its influence on political attitudes. Rap, depending upon the song produced and the lyrics created, can have various effects on the political attitudes and behaviors of the Black community.

\section{Music as Resistance}

Culture is often used to resist dominant ideologies and oppressive situations (Davis 1989; Martinez 1997; Mitchell and Feagin 1995; Zillman et al. 1995). Culture was and continues to be a resistance mechanism utilized by Blacks in America since slavery. Researchers have argued that as they toiled, "through songs slaves could comment on their problems. . they could voice their despair and hopes and assert their humanity in an environment that constantly denied their humanness" (Southern 1997, 156). Enslaved Africans instituted a system of hidden transcripts through culture including music to resist (Southern 1997; Neal 1999).

Music continued its strong relationship between African American suffering, oppression and fight for political inclusion during the Civil Rights era. Black music became more popular among mainstream American audiences because of its political emphasis on the future. Many artists used their songs to give commentary on the issues of the day. For instance, in "Mississippi Goddamn!" singer Nina Simone vented her outrage about the deaths of four little girls in a Birmingham church and other violent acts committed against Blacks in the South (Neal 1999). Music not only provided information and attitudes but it also encouraged dedication, loyalty and persistence during the difficult, contentious times of the Civil Rights Movement (CRM) (Morris 1984) Accounts of the CRM detail the use of music to motivate marchers and reinforce non-violent responses, raise consciousness, provide comfort during times of incarceration, murder and violence and to express emotions during times of pain, suffering, sadness, joy and celebration (Morris 1984; Garofalo 1992). Following the CRM, artists continued to write 
and produce political and socially conscious songs which took a stance against poverty in America, war, cultural pride, determination and segregation as exemplified with Marvin Gaye's "What's Going On," and "Inner City Blues" and Curtis Mayfield's "Keep on Pushing" and "We People Who are Darker than Blue" (Neal 1999). Songs such as James Brown's "Say it Loud: I'm Black and I'm Proud" not only served as background music for the Black Power movement within the Black community, but also increased racial solidarity and consciousness among African Americans (Walker 1975).

\section{Bring the Pain: Political and Social Issues within Hip-Hop}

There are numerous examples in the Hip-Hop community of using rap music to identify and discuss discrimination, poverty, racism, police brutality and other social ills. One song to do this has often been labeled the first political rap song, "The Message," by rap group Grandmaster Flash and the Furious Five (Neal 2004). This song described the reality for many living in urban communities. In this song the artists describe aspects of their lives in urban communities. They comment on the effects of living in harsh impoverished neighborhoods and the impact these conditions have on a person's emotional and mental well-being (Southern 1997). Similar to the previous Bebop era, rap music emerged as a response to the injustices felt in urban communities, primarily in the north. ${ }^{3}$

Using rap to detail the reality of life for many urban Black Americans was necessary as the images propagated in mainstream media only presented a "prototypical" Black character eliminating a diversity of experiences, thoughts and behaviors of urban youth (Neal 2004). Rap has literally brought a voice to a segment of the community that was often alienated and dismissed. Rap allows urban youth to detail their stories and lives from their perspective instead of seeing distorted images of themselves in media, by politicians and through other leaders (Allen 1996; Norfleet 2006; Pough 2004; Rose 1994).

Rap brings alternate images and relevant issues for people of color to the attention of larger society. However, these images may not have been received by mainstream America during the time because of the marginalization of this segment of the community. Hancock (2004) explains this form of silence by asserting that "members of marginal groups, even when granted the power of speech, find their voices deval-

3 In Cathy Cohen's Boundaries of Blackness (1999) she details the concept of marginalization. Stating that marginal groups are "those who exist politically, socially or economically outside of dominant norms and institutions" (Cohen 1999, 37). It can be argued that this marginalization became more evident because of the increased geographical marginalization as a result of the increased poverty in America. 
ued or disrespected, increasing their isolation and alienation from the public sphere" (4). The form of devaluation Hancock describes is prevalent in rap music as observed by the numerous discussions to censor rap as well as deem it as an illogical, turbulent, nihilistic musical form (Carpentier, Knobloch \& Zillman 2003; Johnson, Jackson \& Gatto 1995; Johnson, Trawalter \& Dovidio 2000; Rubin, West \& Mitchell 2001). Observing that music has played an important role in delivering information in the Black community, as a form of resistance throughout American history and as force to raise consciousness, it can be speculated how music affects the Black community politically.

\section{Knowing Political Rap When You See It}

Rap covers a broad spectrum of musical styles. Some rap forms may transcend two or more genres. For instance, some rappers may produce songs that are both political and "gangster" such as artists Niggas With Attitude (NWA), who elaborate on social issues in one track and in the following track, have a song that objectifies women or presents nihilistic attitudes. Political rap is only a component of the larger rap music genre. Identifying a subgenre is essential for the understanding of the impact of media art forms on political attitude acceptance.

Describing political music, some have grouped political songs with socially relevant songs and labeled them message songs. ${ }^{4}$ Another method is to simply refer to artists who have made some political songs and group the artists into a political category (Allen 1996; Decker 1993; Perry 2004; Rose 1994). I, on the other hand, do not categorize artists. It is my belief that musicians change and grow and they cannot be confined to any specific label. Therefore, an artist such as Trick Daddy who began his career rapping with Luke, ${ }^{5}$ and classifies himself as a "thug6" also creates political songs such as "America" and "Thug Holiday." 7 For this reason my basis of examination are the songs and not the artists. Using the songs will allow for inclusion of political rap songs from artists who are not known for producing political rap music. This categorization gives rappers flexibility while still allowing recognition for political participation through their voice. Similarly, Mark Anthony Neal (2006) describes political songs as songs “. . .that contained distinct po-

4 Robert Walker (1976) states in his dissertation on Black music and society that message songs are "songs which symbolized solidarity by relating in a specific way" to one or more solidarity dimensions (p. 7).

5 Luke is a popular artist who was often criticized because of his lewd language but he is widely known for his creation of bass music. This type of music emphasizes sexual contact with underlining bass beats that are often used as party songs in the south.

6 This classification is indicated by his album titles, Book of Thugs and Thug Holiday.

7 This song is political because it makes reference to politics and also discusses a social problem thereby satisfying two criteria of the definition. 
litical commentary. ..." (624). Nevertheless, I argue that political rap is more complicated than simply containing a political reference or commentary. I assert that the inclusion of political references is essential to identifying political songs, but these political references must be accompanied by other criteria in order to be considered a political rap song.

While a lot of scholars discuss the existence and importance of political music, conscious or "message" rap has not been defined by any scholar. Case in point, Ernest Allen Jr., (1996) posits that political rap does exist and it has a direct connection to two important nationalist sects, The Nation of Gods and Earths and the Nation of Islam. ${ }^{8}$ He also suggests as does Errol Henderson (1996) that message or nationalist rap has contributed to greater political and racial consciousness. However, neither of these authors define political rap although both of them give examples of rappers they consider present political lyrics. Decker comes the closest to an actual definition of political rap when he divides rap into two subgenres, Afrocentric Nationalism and what he calls, a sixties-inspired Nationalism. ${ }^{9}$ However, this categorization is limited only to rappers who espouse a Black Nationalist ideology or Black Nationalist themes. Is it possible for rap artists to present political attitudes other than those typically associated with Black Nationalism? If so, how should those songs be categorized? Are they no longer political? I offer a different criterion for identifying and classifying political rap songs.

My criterion for identifying political rap was developed initially by using those artists who were referenced as political or message rappers. Next, I have taken into consideration the varied vague categorizations presented in the literature and the specific definition asserted by Neal and the Centre for Political Song that suggests a political song must have a political reference. Finally, I use a previous categorization that was used to identify message music of the civil rights and the Black Power era by Robert Walker. Walker used three main criteria to identify message songs, which includes 1) songs with implicit or explicit ethnic symbols

8 Allen asserts that there are three categories for political rap, “. . .(1) the Islamic nationalist orientation of rappers such as Pete Rock and C.L. Smooth. . . (2) the cultural-political nationalism of Public Enemy. . . and (3) specific, message-oriented expressions embedded in the more earthy gangsta rap. .."(Allen 1996, 162).

9 Afrocentric Nationalism is more culturally based using Africa, specifically Egypt, as the foundation for Black culture. Decker asserts that Afrocentric Nationalist songs are songs that emphasize African culture with emphasis on specific countries the most popular being Egypt (Decker 1993). In contrast, the sixties-inspired Nationalism focuses more on political and social power. In these songs the artists supports and present rhetoric that was popular during the $60 \mathrm{~s}$ and early $70 \mathrm{~s}$. These groups present Black power attitudes and ideas. He asserts that these types of nationalisms are separated by whether the ideas were extensions of 1960s nationalist rhetoric or whether one agrees that Egypt is the original site of Black culture. He separates these genres by differentiating between time (1960s) and space (Egypt) (Decker 1993). 
2) references "social class problems. ..." and 3) those that refer "to groups other than ethnic or social class. ..." (Walker 1975, 39).

My categorization of political rap is similar to Walker's classification of message songs while I make an original contribution to the discussions of "message" songs by including rap as a genre of interest and emphasizing political references compared to sociological references. While messages are asserted in many political rap songs, a song is only political if it displays an implicit or explicit political reference in the lyrics in addition to satisfying one of two of the other criteria. This prioritization of political references also distinguishes my definition from other attempts to categorize rap as message rap. Therefore, political rap is rap music that must include the first criteria as well as contain either the second or third criteria below:

\section{The Criterion: Knowing Political Rap When you Encounter It}

1. Display political references in the lyrics, such as directly referencing a political leader, political office/institution, political activity, political events or political position.

2. Make reference to a social problem or issue and discuss it in the lyrics, therefore raising awareness about specific issues or disparities nationally or globally by discussing those issues in lyrics.

3. Advocate a solution to injustices or problems in society either through violent or non-violent means.

The song by popular rap artist Nas, "I Want to Talk to You," if examined based on my criteria, is political rap song. We can observe how it fits the categorization and label of political rap song by observing the chorus and a couple of additional lines from the song. In the chorus Nas raps,

I wanna talk to the mayor, the governor, the motherfucking president

I wanna talk to the FBI, and the CIA, and the motherfucking congressman ${ }^{10}$

Here Nas references the mayor, the governor, the president and other political organizations and positions. This song satisfies the first condition by displaying political references. These political references are explicit references. All political references may not be explicit. Sometimes the political references will be implicit using coded language 
or a "hidden transcript," a popular element of Black vernacular, such as references to the system, the man, or other coded words (Scott, 1990; Gates \& McKay, 1997). When coded words are present the decoding is left to the listener to interpret the meaning of the sequence of words and the context in which they are used. Thus, when words are coded it may require more interpretation. Having satisfied the first criteria in order for this song to receive the label of a political rap song at least one of the other criteria must be met. This song goes on to satisfy the second criteria in the second verse where Nas rhymes:

Mr. Mayor imagine if this was your backyard

Mr. Governor imagine if it was your kids that starved Imagine your kids gotta sling crack to survive

In this verse Nas comments on the social condition of poverty in America and what he feels is one of the options of survival for many young Black Americans, namely participating in the illegal drug market by asking politicians how they would feel and react if their children were subjected to that reality of life. With these three lines Nas has satisfied the second category of this criterion by making a reference to poverty, a social condition and discussing it in the lyrics. However, Nas' song is rare because it also satisfies the third condition with the following verse:

I wanna talk to the man understand

Understand this motherfucking G-pack in my hand

In this verse Nas is conveying that he will use weapons or any means to make sure he is heard by those political leaders or have access to them. Simply attempting to talk to those in higher positions about the situations of many African Americans is an example of presenting some solution to the injustice he sees in society. However, he is also advocating a call to arms in efforts to be heard by the various political institutions and politicians.

This political rap categorization is not a catch all criteria. Some songs that may be classified as message songs are not political. Understanding that there are differences in subgenres of rap and that rap music exposure impacts attitudes, it is essential to classify different subgenres of rap music in order to examine what affects the different subgenres have on various attitudes. For instance, we know that gangsta rap leads to more violent and nihilistic behavior and attitudes but how does political rap impact political attitudes (Johnson et al 1995)? What political messages are presented in political rap songs? Being able to identify political rap songs will help us in understanding which Black political ideologies are asserted within political rap songs, a specific subgenre of the rap genre. Having established a criteria to identify political rap, I next turn to the political ideology that is the most prominent within rap 
music, Black Nationalism (Allen 1996; Henderson 1996; Dawson 2001; Harris-Lacewell 2004 and Spence 2012).

\section{Black Nationalism}

Black Nationalism is a very old ideology that has survived through generational shifts, staying mostly intact through existing and past refinements and definitions. Some facets of Black Nationalism are a belief in self reliance, self determination, and community control (Brown \& Shaw 2002; Davis \& Brown 2002; Henderson 1996; Hill-Collins 2006). Black Nationalism as an ideology comprises a set of beliefs that articulate the need for the cultural, political, and economic independence of African Americans (Karenga 2002). Black Nationalism can be defined as "a body of social thought, attitudes and actions ranging from the simplest expressions of [Black] ethnocentrism and racial solidarity to the comprehensive and sophisticated ideologies of Pan-Negroism or Pan Africanism" (Bracey, Meier \& Rudwick 1970, xxvi). As Dawson (1994) explained "the core concepts behind Black nationalism have historically been the development of independent political strategies, Black and African culture, economic independence, and an African American land base" (188). Davis and Brown (2002) contend that "nationalism is a system of thought that contains two components: a sense of political solidarity, consciousness of identity, or a common purpose; and a desire and striving for political self-determination" (240). Similarly Hill-Collins (2006) asserts that nationalism requires the ideas of self-reliance, selfdetermination and self-definition. Its highly racialized agenda makes it one of the dominant ideologies in Black political thought (Walton 1985; Dawson 2001).

Why Black Nationalism? First, because as Alexander-Floyd (2007) and others state, Black Nationalism is "the dominant ideology in contemporary Black Politics," hence it should also be an ideology represented in the smaller rap community (3). Second, being a Black Nationalist makes one more aware of and engaged in issues that affect the Black community. The newly acquired interest that results from Black Nationalist attitudes makes the supporters of these attitudes concerned about political and social issues in their communities which affect political behavior and participation. Finally, according to Lusane (2004) "the dominant ideological trend of the rappers is Black Nationalism" (355). Consequently, many rappers adhere to Black Nationalist ideology that is advanced through the teachings of the Nation of Gods and Earths (NOG\&E), popularly known as the Five Percenters (Miyakawa 2005; Norfleet 2006). In fact, it has been asserted that the Five Percenters deliberately used rap as a means of disseminating their culture, ideas and beliefs (Perry 2004). With many of the artists abiding by Black Nationalist ideology plus the 
continuous references in rap music to Black Nationalist ideology, it is reasonable to expect that Black Nationalism will be a supported and accepted ideology to those who listen to rap and particularly the subgenre of political rap.

A lot of Black Nationalist sentiments that are presented in rap songs may not be as blatant as direct references to Black Nationalist leaders, or “. . .repetitive soundbites from Malcolm X. . ..or Louis Farrakhan strewn together" (Allen 1996, 161). Sometimes the allusions are to Black Nationalist attitudes such as self reliance, self determination, and racial solidarity which include identifying injustices to African Americans. It is easier to identify Black Nationalist references in rap songs that specifically identify Black Nationalist leaders. For instance, in his song "Thug Holiday", Trick Daddy references Black Nationalist leaders Malcolm X and Louis Farrakhan. He states,

And, I read your books know all the remixes to the bible

What about a verse for the thugs, a cure for drugs and survival

Let's add some chapters name them Martin, Malcolm and Farrakhan

Similarly, the rap group Wu-Tang Clan also presented Black Nationalist attitudes by directly mentioning Black Nationalist leaders. This song that features popular blaxplotation musical artist Isaac Hayes, "I Can't go to Sleep," opens by discussing police brutality, racial profiling and interactions with the criminal justice system because of drugs in their community, specifically crack cocaine and the possible government involvement with crack being in the Black community. The second verse deals with political assassinations and exportation of individuals known to be proponents of Black's civil rights. Based on the lyrics by rapper RZA (pronounced rizzah), the listener is informed about politically related assassinations.

These lyrics make specific references to three Black Nationalist leaders, Clarence the 13th X, Malcolm X and Marcus Garvey. The song describes the fate of these nationalist leaders as well as other leaders who were involved in the progression of race relations in the United States. ${ }^{11}$ In this verse the listener is prompted to recall famous Black leaders. The first leader referenced is Clarence 13th $\mathrm{X}$, who is known as the founder of the religious sect, the Nation of Gods and Earths (NG\&E) and was

11 The reference to the father in the above verse is referencing Clarence the 13th $\mathrm{X}$ who is known as the father of the Nation of gods and earths or the five percenters. Clarence the 13th $\mathrm{X}$ received his name when he was a member of the Nation of Islam. He subsequently left the NOI and started Five Percent using many of the teachings from the NOI plus adding some of his own ideas (Miyakawa 2005). 
shot seven times and killed (Miyakawa 2005). The second leader referenced is Malcolm X (El Hajj MalikEl- Shabazz), former leader and spokesperson of the Nation of Islam who was assassinated in the Audubon Ballroom in 1965 in front of his wife and four children. Next RZA mentions Martin Luther King Jr, leader of the Southern Christian Leadership Conference (SCLC) and promoter of non-violent resistance for the Civil Rights Movement (CRM) in the United States. King was assassinated at the Lorraine Motel in Memphis Tennessee in 1968 surrounded by Black leaders Jesse Jackson and Ralph Abernathy. RZA then references another Black Nationalist leader, Jamaica native and the founder of the Universal Negro Improvement Association (UNIA) and the shipping line the Black Star Line, Marcus Garvey. Unlike the other victims in this verse, Marcus Garvey was not killed but instead was indicted of alleged mail fraud, imprisoned and ultimately deported back to Jamaica. Garvey was known as the creator of the Black liberation flag (red, black and green colors) and as having millions of followers internationally. RZA continues on by discussing assassinations of other leaders including John F. Kennedy and Medgar Evers. Thus, what RZA does in this verse is promotes a remembrance and education of these leaders, their untimely deaths and deportation and possible governmental involvement, which promotes a distrust of government, especially in aspects of dealing with African Americans fight for universal freedom and inclusion. Directly identifying nationalist leaders in lyrics can work to prime listeners for nationalist views through the invocation of Black Nationalist leaders.

Contrarily, not all songs blatantly identify Black Nationalist leaders. Some songs reference Black Nationalist attitudes such as racial consciousness as expressed in Too \$hort's song "The Ghetto." In this song Too \$hort expresses:

So much game in a Too \$hort rap

Blacks can't be White and Whites can't be Black

Why you wanna act like someone else?

All you gotta do is just be yourself

We're all the same color underneath

Short Dog's in the house you 'd better listen to me

Never be ashamed of what you are

Proud to be Black stand tall at heart

Even though some people give you no respect

Be intelligent, when you put em in check

Cause when you're ignorant, you get treated that way

In this verse the rapper expresses his racial pride, which is a prominent trait of cultural Black Nationalist sentiment, as well as discusses the relationships he feels exist between Blacks and Whites. He details that while he is prideful he may not receive adequate respect from other racial 
groups. These sentiments demonstrate the internalized marginalization and hostility felt by many African Americans which promotes racial consciousness and group cohesiveness. But racial pride is not the only Black Nationalist attitude you can find in political rap songs. Sometimes the allusions are to Black Nationalist attitudes such as self reliance, self determination, racial consciousness and racial solidarity as expressed in New York rapper Nas's song, "Black Zombies:"

In this song, Nas invokes the Black Nationalist attitude of self-reliance. Nas advocates Black-owned businesses, banks, and land as remedy for dependence on American [white] political, social and economic systems. In other words, owning, investing and controlling businesses, the economy and land, according to Nas, will help end the control, oppression, and "zombie"-like state of African Americans in America. Throughout this song he discusses various ways he believes African Americans are "zombies," those without the ability to reason and control their own desires, thoughts and actions. While Nas primarily prescribes self-reliance and self-determination, he also summons racial consciousness and solidarity.

More recent and popular political rap songs have also supported and presented Black Nationalist attitudes in its lyrics. For instance, rapper Jadakiss' 2004 political song "Why" was featured on The O'Reilly Factor, a right-leaning news show hosted by conservative commentator, Bill O'Reilly on Fox News. O'Reilly, a vocal critic of rap music, featured the song because he believed that it was an "atrocity" and offered a biased view of the Republican administration (Heim 2004). Jadakiss' song, a top 20 single on the Hip-Hop charts, posed many titillating political questions about past president George W Bush, the Republican administration, the 2000 national election, and the events of September 11, 2001 (Heim 2004). After controversy erupted over the original version, a remix featuring rappers, Styles $\mathrm{P}$, Common and Nas was released. While the initial song had focused on the events of 9-11, the remix touched on themes as diverse as partisanship and race, the 2000 presidential election, George W. Bush, the war on terror, Barack Obama, Malcolm X, and the education system. More importantly for my purpose here, the remix presented aspects of Black Nationalist ideology. For instance, Styles P, member of the rap group The L.O.X. with Jadakiss, questions,

Why vote Republican if you Black. ...

In this lyric, Styles P questioned the logic of voting for the Republican Party if you are Black, because of the belief that the Republican Party does not advance issues relevant to African Americans and Michael Dawson's linked fate theory which argues that African Americans lack of support or allegiance to parties that do not align with issues relevant to the Black community (full employment, welfare reform inclu- 
sive of a guaranteed income, comprehensive health care and minority business set asides) regardless of individual class differences (Williams 2003; Dawson 2004; Walton and Smith 2010) ${ }^{12}$. In fact, the Republican Party has been known to advance implicit racial messages advocating against African American participation (Mendelberg 2001). But Styles P was not the only rapper in the remix to assert Black Nationalist sentiments in his verse. The recently invited Chicago rapper to the White House's poetry event, Common, took it a step further and advocated for an administration change.

Why is Bush acting like he trying to get Osama

Why don't we impeach him and elect Obama

Common appeals to Black Nationalist attitudes by suggesting the election of then Senator Barack Obama to the office of President of the United States, and is thus supporting a Black candidate as a means of inclusion and empowerment within the political system, an aspect of Black Nationalist sentiments of voting for Black candidates. Common could have proposed another solution to the problem with the Bush administration but instead he chose to appeal to Black sentiments and the belief that electing a Black official had the potential to eliminate problems and gain concessions. Finally, Nas is more obvious with his Black Nationalist appeals by making a direct reference to Black Nationalist leader Malcolm X in his verse suggesting that Blacks should continue Malcolm X's mission. Hip-Hop is therefore inextricably connected to Black Nationalist paradigms and philosophies, specifically political rap.

\section{Conclusion}

It is suggested that the ". . . search for Black ideology must begin with the oral tradition" and this article examines one aspect of the oral tradition, rap music, specifically political rap and its relationship with Black Nationalist ideology (Henry 1990, 7). Rap music can frame an idea or viewpoint, set an agenda on a political issue as well as prime certain ideas or make them more accessible. With Hip-Hop music being situated as a popular music source; its influence on the attitude formation of individuals is important.

In research, political scientists rarely include rap as a media outlet that provides political information and impacts a person's political attitudes. This article has made the case for the consideration of rap as a

12 Some would argue that because of economic attainment some Blacks should align with the Republican party because of their emphasis on tax cuts for members of the upper class. But Dawson concludes that even when economic situations change African Americans align with political parties that discuss more issues relevant to them. 
relevant and powerful factor in the formation of political ideology. Rap music can frame an idea or viewpoint, set an agenda on a political issue as well as prime certain ideas or make them more accessible. Powell (1991) asserts that “. . . in addition to entertainment, rap music provides a significant form of informal education for adolescents . . . that extends far beyond the confines of the classroom and into their peer group circles" (p. 245). This article provides vital information and examples of the relationships between rap music and Black Nationalism. What Harris-Lacewell (2004) contends is correct, there are various avenues through which African Americans receive political information that assist in the formation of political attitudes and rap music happens to be one of them.

Why haven't we observed this before? One of the possibilities why the socialization potential of rap music has not been examined within political science is because politically laced rap is not as popular as mainstream rap and therefore is not as prominent in mainstream society. Another possibility is the actions and attitudes that stem from political rap have been attributed to other political sources. However, this is not a reason to discount the influence of the subgenre. Understanding marginalized communities must include examination of marginalized cultural forms within the community. While many aspects of rap are still seen as deviant there is an understanding that this cultural art form is also important to behavior and attitudes. With the significant impact HipHop has not only on American culture, but other cultures, the study of the relationship between Hip-Hop culture, rap music, political behavior and political ideology is not only necessary in the United States but will become more relevant on an international level as Hip-Hop gains popularity.

\section{REFERENCES}

Alexander-Floyd, Nicole G. 2007. Gender Race and Black Nationalism in Contemporary Black Politics. New York: Palgrave McMillian.

Allen, Ernest. J. 1996. "Making the Strong Survive: The Contours and Contradictions of Message Rap." in Droppin' Science: Critical essays on Rap Music and Hip Hop Culture, edited by W.E. Perkins. Philadelphia, PA: Temple University Press.

Ards, Angela. 2004. "Organizing the Hip-Hop Generation." in That's the Joint: The Hip-Hop Studies Reader, edited by M. Forman and M.A. Neal. Ithaca, NY: Routledge.

Bracey, John. H., August Meier, and Elliot. Rudwick. 1970. Black Nationalism in America. Indianapolis, IN: The Bobbs-Merrill Company, Inc. 
Brown, Robert A. and Todd C. Shaw. 2002. Separate Nations: Two Attitudinal Dimensions of Black Nationalism. The Journal of Politics 16(1): 22-44.

Carpentier, Francesca. D., Silvia Knohbloch, and Dolf. Zillman. 2003. "Rock, Rap and Rebellion: Comparisons of Traits Predicting Selective Exposure to Defiant Music." Personality and Individual Difference 35(7): 1643-1655.

Cohen, Cathy. 1999. Boundaries of Blackness: AIDS and the breakdown of Black Politics. Chicago, IL: University of Chicago Press.

- 2010. Democracy Remixed: Black Youth and the Future of American Politics. New York, NY: Oxford University Press.

Davis, Angela. 1989. Women Culture and Politics. New York. Random House.

Davis, Darren. W., and Ronald E. Brown. 2002. "The Antipathy of Black Nationalism: Behavioral and Attitudinal Implications of an African America Ideology." The American Journal of Political Science 46(2): 239-253.

Dawson, Michael. C. 1994. Behind the Mule: Race and Class in African-America Politics. Princeton, NJ: Princeton University Press.

1999. "Dis Beat Disrupts." The Cultural Territories of Race: Black and White Boundaries, edited by M. Lamont. Chicago, IL: University of Chicago Press.

- 2001. Black Visions. Chicago: Illinois. The University of Chicago Press.

Decker, Jeffrey. L. 1993. “The State of Rap: Time and Place in Hip Hop Nationalism." Social Text 34: 53-84.

Garofalo, Reebee. 1992. "Popular Music and the Civil Rights Movement." in Rockin' the Boat: Mass Music and Mass Movements, edited by R. Garofalo. Cambridge, MA: South End Press.

Gates, Henry. L. Jr. and N.Y. McKay, ed. 1997. The Norton Anthology African American Literature. New York: W.W. Norton and Company.

Hancock, Ange-Marie. 2004. The Politics of Disgust: The Public Identity of the Welfare Queen. New York: New York University Press.

Harris-Lacewell, Melissa. 2004. Barbershops, Bibles and BET. Princeton, NJ: Princeton University Press.

Henderson, Errol. 1996. "Black Nationalism and Rap Music." Journal of Black Studies 26(3): 308-339. 
Henry, Charles. 1990. Culture and African American Politics. Bloomington, IN: Indiana University Press.

Hill-Collins, Patrica. 2006. From Black Power to Hip Hop. Philadelphia, PA: Temple University Press.

Iton, Richard. 2007. In Search of the Black Fantastic: Politics and Popular Culture in the Post-Civil Rights Era. New York, NY. Oxford University Press.

Johnson, James. D., Lee A. Jackson, and Leslie. Gatto. 1995. "Violent Attitudes and Deferred Academic Aspirations: Deleterious Effects of Exposure to Rap Music on Stereotypical Attributions to Blacks." Basic and Applied Social Psychology 16(1): 27-41.

Johnson, James. D., Sophie Trawalter, and John.F. Dovidio. 2000. "Converging Interracial Consequences of Exposure to Violent Rap Music on Stereotypical Attributions of Blacks." Journal of Experimental Social Psychology 36(3): 233-251.

Kitwana, Bakari. 2002. The Hip Hop Generation. New York: Basic Civitas Books.

Levine, Lawrence. W. 2006. "African American Music as Resistance." in African American Music: An Introduction, edited by M. V. Burnim and P. K. Maultsby. New York: Routledge.

Lusane, Clarence. 2004. "Rap, Race and Politics." in That's the Joint: The Hip-Hop Studies Reader, edited by M. Forman and M. Anthony. New York: Routledge.

Martinez, Theresa. A. 1997. "Popular culture as Oppositional Culture: Rap as Resistance." Sociological Perspectives 30(20): 265-286.

Miyakawa, Felicia. M. 2005. Five Percent Rap: God Hop's Music, Message and Black Muslim Mission. Bloomington, IN: Indiana University Press.

Morris, Aldon. 1984. The Origins of the Civil Rights Movement: Black Communities Organizing for Change. New York: Free Press.

Neal, Mark. A. 1999. What the Music Said: Black Popular Music and Black Public Culture. New York: Free Press.

2004. "Postindustrial Soul: Black Popular Music at the Crossroads." in That's the Joint: The Hip Hop Studies Reader, edited by M. Forman and M. A. Neal. New York: Routledge.

. 2006. "Post-Civil Rights Period." in That's the Joint: The Hip Hop Studies Reader, edited by M. Forman and M. A. Neal. New York: Routledge. 
Norfleet, Dawn. M. 2006. "Hip Hop and Rap." in African American Music: An Introduction, edited by M. E. Burnim and P. K. Maultsby. New York: Routledge.

Ogbar, Jeffrey O. G. 2008. Hip Hop Revolution: The Culture and Politics of Rap. Lawrence, Kansas: University of Kansas Press.

Perry, Imani. 2004. Prophets of the Hood: Politics and Poetics in Hip Hop. Durham, NC: University Press.

Pough, Gwendolyn. D. 2004a. Check it While I Wreck It. Boston, MA: Northeastern University Press.

G. D. 2004b. "Seeds and Legacies: Tapping the Potential in Hip Hop." in That's the Joint: The Hip Hop Studies Reader, edited by M. Forman and M. A. Neal. New York: Routledge.

Powell, Catherine. T. 1991. "Rap Music: An Education with a Beat from the Street." Journal of Negro Education 60(3): 245-254.

Rose, Tricia. 1994. Black Noise: Rap Music and Black Culture in Contemporary America. Hanover, NH: Wesleyan University Press.

Rubin, Allen M.,Daniel West, and Wendy.S. Mitchell. 2001. "Differences in Aggression, Attitudes Toward Women and Distrust as Reflected in Popular Music Preferences." Media Psychology 3(1): 2542.

Scott, James. C. 1990. Domination and the Arts of Resistance: Hidden Transcripts. New Haven, CT: Yale University Press.

Spence, Lester 2011. Stare in the Darkness: The Limits of Hip-hop and Black Politics. Minneapolis: Minnesota. The University of Minnesota Press.

Southern, Eileen. 1997. The Music of Black Americans: A History. 3rd ed. New York: Norton and Company.

Walker, Robert. G. 1975. Society and Soul. Unpublished doctoral dissertation. Stanford, CA: Stanford University.

Walton, Hanes. Jr. 1985. Invisible Politics: Black Political Behavior. New York: State University of New York Press.

\section{DisCOGRAPHY}

Fletcher, Ed "Duke Bootee", Grandmaster Melle Mel, Bobby Robinson. 1982. "The Message." Recorded by Grandmaster Flash and the Furious Five. The Message. Vinyl. Engle Wood, New Jersey. Sugar Hill Records. Rap lyrics retrieved from http://www.ohhla.com.

Jones, Nasir H. (Nas), Lesham Lewis, Alvin West. 1999. "I Want to Talk to You." Recorded by Nas. Nas I Am . . The Autobiography. 
Compact Disc. New York, New York. Columbia Records. Rap lyrics retrieved from http://www.ohhla.com.

Phillips J., (Jadakiss) A. Hamilton, K. Muchita, and P Moerlen. 2004. "Why" Recorded by Jadakiss featuring Anthony Hamilton, Common, Nas and Styles P. Kisss of Death. Compact Disc. Ruff Ryders. Interscope Records. Rap lyrics retrieved from http:// www.ohhla.com.

Shaw, Todd (Too \$hort). 1990. “The Ghetto.” Recorded by Too \$hort. Short Dog's in the House. Compact Disc. Jive Records. Rap lyrics retrieved from http://www.ohhla.com.

Trick Daddy and Society. 2000. “America." Recorded by Trick Daddy. Book of Thugs: Chapter AK verse 47. Compact Disc. Miami, Florida. Slip $-\mathrm{N}$ - Slide Records, Inc. Rap lyrics retrieved from http://www.ohhla.com.

Wu-Tang Clan and Isaac Hayes. 2000. "I Can't Go to Sleep." The W. Compact Disc. New York, New York. 36 Chambers Studio and Los Angeles, California. Track Records, Inc. Rap lyrics retrieved from http://www.ohhla.com. 